J. Nat. Hist. Mus. Vol. 30, 2016-18 269-273

\title{
Gastrointestinal parasites of Emu (Dromaius novaehollandiae Latham, 1790) in Ostrich Nepal Pvt. Ltd Gongoliya, Rupandehi, Nepal
}

\author{
Kamala Khatri' and Mahendra Maharjan ${ }^{1} \bowtie$ \\ ${ }^{1}$ Central Department of Zoology, Tribhuvan University, Kirtipur, Kathmandu, Nepal \\ mmaharjan@cdztu.edu.np
}

\begin{abstract}
Ostrich and Emu farming have been lunched with a very new concept to Nepalese market for their product in which parasitic diseases may cause significant effect to their production. In order to determine prevalence of gastrointestinal parasites of Emu,a total of 100faecal samples were collected during the month of May/July 2015. All samples were microscopically examined by using direct smear and concentration techniques (floatation and sedimentation). Out of 100 faecal samples, $65 \%$ were found positive for gastrointestinal parasites. Overall, seven different species of gastrointestinal parasites including two protozoan, three nematodes and two cestodeswere recorded. Amongprotozoan parasites, Eimeria sp. (30\%) was more prevalent compared to Entamoeba sp.(10\%). Among helminthes parasites, Ascaris sp. (15\%) showed the higher prevalence rate followed by Dromaestrogylus sp. (10\%), Davainea sp. (9\%), Raillietina sp. (5\%) and Heterakis sp. (5\%). This study suggested that parasitic infection could be a serious problem in the farm hence needed to adopt appropriate control strategies in order to strengthen the successful emu production in Nepal.
\end{abstract}

Keywords: prevalance, Eimeria, Entamoeba, Davainea, Raillietina, Dromaestrongylus.

\section{INTRODUCTION}

Emu (Dromaius novaehollandiae) is second largest, flightless bird of the world belonging to the order, Ratite with flat breast bone (Jeffery, 1996; Patodkar et al., 2009; Bennett et al., 2013). They are only bird with gastrocnemius muscles in the back of the lower legs which facilitate them to run at the speed of $48 \mathrm{~km} / \mathrm{hr}$ (Patodkaret al., 2009). IUCN considered emu population trend to be stable and assesses their conservation status as being of least concern (Bird Life International, 2015).

In most part of the world ratite farming is a new field of livestock production (Nemejc, 2007). Just like ostrich farming, Emu farming has become popular and lucrative agricultural industry throughout the world (Orumbayer, 2015). Globally, the population of Emu is estimated to be around two million in which one million is spread between North America, Peru, India and China and about 750,000 in Australia (Orumbayer, 2015). In Nepal, there is only one Emu farming at Ostrich Nepal Pvt. Ltd. Gongoliya, Rupendehi which was established in 2008 AD for commercial purpose by importing eggs and bird from Australia.

Health problem in Emu mainly appear in chicks and juvenile stage (Warale et al., 2014). Both 
wild and captive Emu may be infected with their own specific parasite as well as external and internal parasites of other birds and animals (Nemejc \& Lokesova, 2012). These problems in Emu can cause great economic losses (Tully \& Shane, 1996). Usually careless management, high bird density as well as poor hygiene contribute to parasitic infection (Chang Reissig et al., 2001). To the best of our knowledge gastrointestinal parasites of Emu has not been reported from Nepal yet. This study will help to develop control strategy against gastrointestinal parasites of Emu.

\section{MATERIALS AND METHODS}

The study was carried out at Ostrich Nepal Pvt. Ltd. Gongoliya-22, Tilottama Municipality, Rupendehi district, Nepal. Gongoliya is situated three kilometer east from Madhaulia, Siddhartha highway. A total 1500 birds were reared in five different farms.

A total of 100 faecal samples were collected from the study area during the month of May/ July 2015 . Faecal samples were preserved in $2.5 \%$ potassium dichromate for preserving both helminth eggs and protozoan cysts. Faecal samples were examined under the microscope at the laboratory of Central Department of Zoology Tribhuvan University, Kirtipur, Kathmandu. Both direct smear and concentration method (Floatation and Sedimentation) were followed. Identification of the parasitic oocysts, cysts, trophozoites and eggs were done along with the published literature (Forety, 2005; Teixeira, 2013).

\section{RESULTS AND DISCUSSION}

\section{General prevalence of gastrointestinal parasites in Emu}

The prevalence of gastrointestinal parasites in Emu was found to be $65 \%$. Among 100 samples examined, $37 \%, 24 \%$ and $14 \%$ samples were found to be positive for protozoan, nematode and cestode parasites respectively (fig.1).

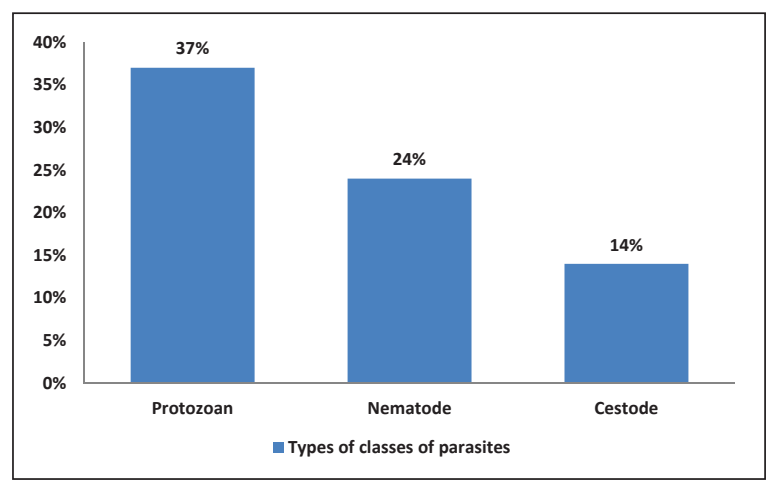

FIG. 1. Class-wise prevalence of gastrointestional parasites in Emu.

A total of seven different gastrointestinal parasites were identified from Emu. Identified parasites includes two species of protozoan (Entamoeba sp. and Eimeria sp.), three species of nematodes (Ascaris sp., Dromeastrongylus sp. and Heterakis sp.) and two species of cestoda (Davainea sp. and Raillietina sp.) but trematodes were not observed during the study. Among 
the protozoan parasites, highest prevalence rate was obserbedfor the coccidian parasite, Eimeria sp. (30\%) as compared to Entamoeba sp. (10\%). The most prevalent helminth parasites was Ascaris sp. (15\%) followed by Dromaestrongylus sp. (10\%), Davainea sp. (9\%), Heterakis sp. (5\%) and Raillietina sp. (5\%) (fig.2).

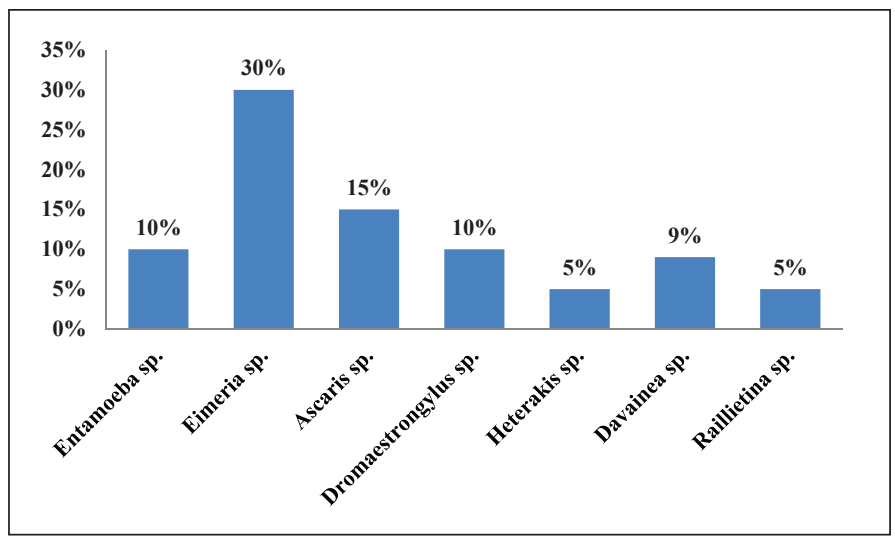

FIG. 2. Species-wise prevalence of gastrointestinal parasites in Emu.

In the present study, $48 \%$ of the samples were found to be positive for single infection followed by double (16\%) and multiple infections (1\%) (fig.3).

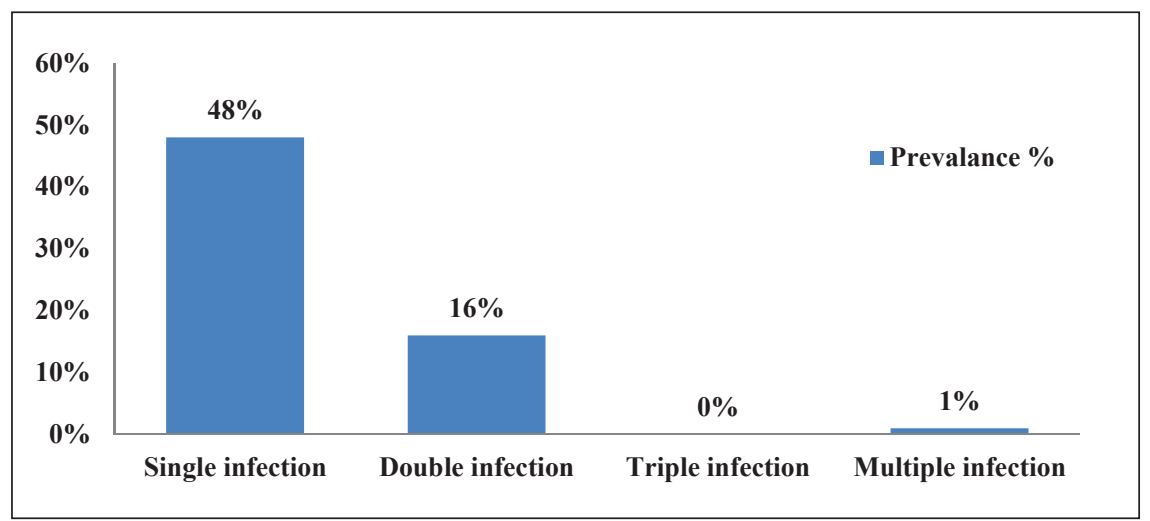

FIG. 3. Mixed gastrointestinal parasitic infection in Emu.

The prevalence of gastrointestinal parasites of Emu (Dromaius novaehollandiae) has been carried out for the first time from Nepal. The result revealed the high prevalence of gastrointestinal parasites in Emu. This high rate of gastrointestinal parasites may be due to the poor hygiene and sanitation and high bird density in the farm (Chang Reissig, 2001). Both protozoan and helminth parasites are transmitted mainly by contaminated water or food while the genus Strongyloides are transmitted by larvae present in the soil through skin penetration (Neves, 2005). Out of 100, 37 samples (37\%), 24 samples (24\%) and 14 samples (14\%) were found positive for protozoan, nematodes and cestodes infections respectively.Eimeria sp. is the most common coccidian 
parasites among juvenile Emu chick. Both/sospora and Eimeria sp. have been recorded from Emu (Papini et al., 2012; Teixeira, 2013). While only the prevalence of oocyst of Eimeria sp. $(30 \%)$ was reported from present study. Ratites have been found susceptible with Giardia sp. (Ponce Gordo et al., 2002; Foreyt, 2005). Cyst and trophozoites of Giardia sp. were identified in Emu (Teixeira, 2013) but these parasites were notfound in present study. Cyst of Entamoeba sp. $(10 \%)$ has been reported in present study as reported by Teixeira (2013).

Similarly, among the nematode, eggs of Ascaris sp. has been reported from study area as reported by Teixeira (2013). Strongyloide nematode i.e. Dromeostrongylus sp. is a parasites of intestine and major endoparasites of Emu (Foreyt, 2005). Eggs and larva of such type of strongyloide have been diagnosed in emu (Teixeira, 2013). Egg of Dromeostrongylus with prevalence rate $(10 \%)$ was isolated in Emu during the study but no adult worms and larvae were recovered. Heterakis dispar, a nematode has been recorded in the alimentary canal of Ostrich of Iran (Eslami et al., 2007) has also been reported in present study with prevalence rate of 5\%.

Another host specific cestode parasites of Emu i.e. Davainea sp. has been isolated in small intestine of Emu (Foreyt, 2005). During the study egg of Davainea sp. has been reported from Emu and the prevalence was found to be (9\%). Different types of Raillietina sp. were previously described from the small intestine of farmed and wild Emu from South Australia (O'Calleghan et al., 2003). In the study, Raillietina sp. has been also reported with prevalence rate (5\%). But trematodes were not observed during the study. However, an adult fluke of Fasciola hepatica has been recovered from Emu (Vaughan et al., 1997; Soares et al., 2007). Out of 100 samples, single infection was found to be highest with $48 \%$ followed by double $(16 \%)$ and multiple $(1 \%)$.

Though, Emu are more parasites free and parasites are not common problems than other ratites but the result concluded that the parasitic burden in Emu of study area showed high. These can cause serious problems leading great economic losses. Thus, it is necessary to treat in order to get maximum benefit. The most scientific publications and articles all over the world are devoted to Ostriches but very few materials are focused on aspects of Emu on health care and related problems.

\section{ACKNOWLEDGEMENTS}

We would like to express our gratitude to the managing director, Mr. C. P. Sharma for the permission given to carry out this study in Ostrich Nepal Pvt. Ltd., Gongoliya, Rupendehi and also for the staff who helped during sample collection. We would also extent thank to Central Department of Zoology for providing laboratory facilities.

\section{REFERENCES}

BENNETT, D C; TUTUN, H M; KIM, J E; LEUNG, F C; CHENG, K M (2013) Characterization of cecalmicrobiota of the Emu (Dromaius novaehollandiae). Veterinary Microbiology Journal 166(2): 304-310.

BIRDLIFE INTERNATIONAL (2012) Dromaius novaehollandiae. IUCN Red List of Threatened Species. Version 2013.2. International Union for Conservation of Nature.

CHANG REISSIG, E; OLAECHEA, F; ROBLES, C A (2001) Parasitological findings of Lesser Rhea (Pterocnemia pennata) in faeces from Northern Patagonia, Argentina. Archivos de Medicine Veterinaria 33: 247-251. 
ESLAMII, A; RAHMAT, H; MESHGI, B; RANJBAR-BAHADORI, S (2007) Gastrointestinal parasites of Ostrich (Struthio camelus domesticus) raised in Iran. Iranian Journal of Veterinary Research 8:80-82.

FOREYT, W J (2005) Parasites of ratites. Parasitology Veterinaryn -Reference Manual. Roca, São Paulo; pp 181-184 (5th edition).

JEFFERYY, J S (1996) Emu production. Texas Agricultural Extension Services Bulletin. Texas A and M University, Texas, USA; pp 1-4.

NEMEJC, K (2007) Ostrich farm management and its perspectives in conditions of the Czech Republic. B.Sc. Thesis, Institute of Tropics and Subtropics, Czech University of Life Science, Prague, The Czech Republic.

NEMEJC, K; LUKESOVA, D (2012) Parasiticfauna of Ostriches, Emus and Rheas. Agricultura Tropica ET Subtropica 45(1): 45-50.

NEVES, D P (2005) Human parasitology. São Paulo, Atheneu; 494 pp (11th edition).

O'CALLAGHAN, M G; DAVIES, M; ANDREWS, R H (2000) Species of Raillientina Fuhrmann 1920 (Cestoda: Davaineidae) from the Emu (Dromaius novaehollandiae). Transactions of the Royal Society of South Australia Incorporated 124(2): 105-116.

ORUMBAYEV, A (2015) A study on breeding proportions of Emu. International Journal of Poultry Science 14(2): 89-91.

PAPINI, R; GIRIVETTO, M; MARANGI, M; MANCIANTI, F; GIANGASPERO, A (2012) Endoparasite Infections in Pet and Zoo Birds in Italy. The Scientific World Journal 2012:1-9.

2012:1-9

PATODKAR, V R; RAHANE, S D; SHEJAL, M A; BELHEKAR, D R (2009) Behavior of Emu bird (Dromaiusnovaehollandiae). Veterinary World 2(11): 439-440.

PONCEGORDO, F; HERRERA, S; CASTRO, AT; GARCIADURAN, B; MARTINEZ DIAZ, R A (2002) Parasites from farmed Ostriches (Struthio camelus) and Rheas (Rhea americaba) in Europe. Veterinary Parasitology 107: 137-160.

SOARES, M P; DASILVA, S S; NIZOLI, L Q; FELIX, S R;SCHILD, A L (2007) Chronic fascioliasis in farmed and wild Greater Rheas (Rhea americana). Veterinary Parasitology145: 168-171.

TEIXEIRA, D S T (2013) Enteroparasites attacking observed in faeces of Emu, Dromaius novaehollendiae Latham, 1790. M.Sc. Thesis, Center of the non-Agricultural Science and Technology of the Universidade Esta dual de Norte Fluminanse Darcy Ribeiro.

TULLY, T N; SHANE, S M (1996) Husbandary practices as related to infectious and parasitic diseases of farmed raratie. Revue Scientificque Technque International Office of Epizootics 15: 73-89.

WARALE, R H; CHAUHGAN, H D; PARMAR, D; KULKARNI, R C; SRIVASTAVA, A $\mathrm{K}$;MAKWANA, R B (2014) Emu farming: an alternative to Indian poultry. Trends in Veterinary and Animal Science 1: 9-14.

VAUGHAN, J L; CHARLES, J A; BORAY, J C (1997) Fasciola hepatica infection in farmed Emus (Dromaius novaehollandiae). Australian Veterinary Journal 75(11): 811-813. 